\section{STI \\ Studies}

www.sti-studies.de

\title{
How Experts Draw Boundaries \\ Dealing with Non-Knowledge and Uncertainty in Prenatal Testing
}

\author{
Alexander Bogner (Institute of Technology Assessment, Austrian Academy \\ of Sciences, Vienna)
}

received 11 March 2005, received in revised form 3 June 2005, accepted 16 June 2005

\begin{abstract}
Categorical distinctions such as healthy/sick or dead/alive serve to provide orientation and to facilitate decision-making in medicine. This is a major issue in the theory of reflexive modernisation. Recently, new scientific nsights within genetics have increasingly prompted the re-drawing of such boundaries. Taking the example of prenatal testing, with particular reference to late term abortion, I investigate the governing rationalities of experts' boundary politics. It will be shown hat boundary drawing is structured with reference to society's guiding principles and notions of normality. In those problematic cases where the medical frame is unable to deliver sufficient interpretative power, this reference to societal value orientations turns out to be functional for maintaining the experts' professional authority. In the case of prenatally diagnosable disabilities, for example, experts often do not know how to deal with such diagnoses. This ambiguity is for the most part understood as (cognitive) uncertainty amenable to more research, rather than interpreted as non-knowledge with reference to the level of social action which results from the interpretative failure of biomedical frames. Thus, the interpretation of non-knowledge appears to become unambiguous, which undermines any pending politicisation of non-knowledge. The alignment with society's guiding principles turns out to be functional for maintaining the claim to be able to provide adequate and relevant information and terms for decision-making processes; in other words, for maintaining professional authority. On the basis of the observation that experts have to deal with uncertainty and non-knowledge, the article asks in conclusion whether this could point to the possible emergence of a reflexive type of expert.
\end{abstract}




\section{Introduction}

Seen from the perspective of sociology, human genetics and reproduction medicine are a dynamic technological field which not only implies a higher degree of control in terms of the circulation of expert knowledge, but above all introduces new uncertainties and design necessities. For example, Giddens (1991) has employed the term 'life politics' as a way of analysing reproductive medicine as a motor for the transformation of identity practices and a new active politics of the physical.

The following discussion does not address these newly emerging design necessities on the level of everyday life and common normalised handling of new technologies. Rather, it is the level of professional action and decisionmaking that is of interest here. Especially in the field of prenatal testing, technological progress has overextended institutionalised decisionmaking conventions, resulting in novel requirements for decision-making and design. In connection with the theory of reflexive modernisation, this process is discussed with reference to the concept of boundary blurring ("Entgrenzung"). ${ }^{1}$ In our case, this term refers to the growing ambiguity of categorical distinctions (Beck/Bonß/ Lau 2004: 40-41). Such 'boundary work' performed by experts is ac-

\footnotetext{
1 "Entgrenzung" means a process of transgressing boundaries or, in a narrower sense, a process in which boundaries become insignificant or irrelevant. Boundary blurring cannot be equated with dedifferentiation ("Entdifferenzierung"), but refers to phenomena below the level of functional subsystems. Boundary blurring is frequently discussed in sociology, in various fields: in connection with flexibilisation and autonomisation ("Eigenarbeit") (Minssen 2000; Kratzer 2003), with the blurring of enterprise boundaries (Powell 1991; Sauer/Döhl 1997), with globalisation and sub-politicisation (Castells 1996; Beck 1986), and in discussions of the complete dissolution of the subject-object differentiation with hybridisation (Latour 1993).
}

knowledged as an institutional necessity, not merely a legitimisation strategy of a particular profession.

The modern biomedical sciences are a fruitful field for the analysis of phenomena of boundary blurring. In the case of Chorea Huntington, a monogenetic hereditary disease, the basic principle of distinguishing between healthy and sick starts to shift due to the divergence between possible early detection and the late manifestation of symptoms. Is someone who does not yet have symptoms healthy, or sick because he bears the genetic disposition which will inescapably lead to the manifestation of the disease (Scholz 1995: 48)? Breast cancer provides a further illustration. Although this disease is attributed to a genetic component, $^{2}$ no strong causality between a specific DNA sequence and phenotype has yet been demonstrated. Consequently, it is only possible to prognosticate the risk of disease, the extent of which remains mostly uncertain (Lemke 2004: 71). The distinction healthy/sick therefore becomes blurred on the level of aetiology. Another example is stem cell research. In the ongoing ethical debate relating to the destruction of embryos as an inevitable consequence of growing embryonic stem cell lines, it has become obvious that a scientific cetermination of the beginning of life is not possible. Bioethical debates, as a consequence, relate to the pluralisation of the life/death distinction (Viehöver 2005).

Cognition-oriented and decisionrelieving boundary constructs in prenatal testing are also being stretched to the limit as a result of increasing scientification and advances in medicine. My interest focuses on the reaction modes of experts, as well as on the consequences of these modes of

\footnotetext{
${ }^{2}$ Currently it is assumed that mutations of both genes, BRCA1 and BRCA2 ('breast cancer'), which serve to protect against tumour growth, contribute to the manifestation of breast cancer.
} 
dealing with uncertainty and nonknowledge. In the following I will argue that the ways in which experts draw boundaries are structured with reference to society's guiding principles (like autonomy, self-awareness and individual responsibility) and notions of normality.

In those problematic cases where the medical frame is unable to deliver sufficient interpretative power, this reference to societal value orientations turns out to be functional for maintaining the experts' professional authority. In the case of prenatally diagnosable disabilities, for example, experts in many cases do not know how to deal with such diagnoses. This ambiguity is for the most part understood as (cognitive) uncertainty amenable to more research, rather than interpreted as non-knowledge with reference to the level of social action which results from the interpretative failure of biomedical frames. Thus, the interpretation of non-knowledge appears to become unambiguous, which undermines any pending politicisation of non-knowledge. The alignment with society's guiding principles turns out to be functional for maintaining professional authority.

A challenge for this authority arises from prenatal testing being still ethically controversial. In addition, public debates sustain about whether or not the ideology of eugenics and of human genetics tend to converge. By professional authority I understand human genetics' claims of competence for the explanation of the phenomenon of disability based on the legitimacy to subsume pertinent phenomena within the professional interpretation and relevance framework. In other words, professionals claim to be able to provide adequate and relevant information and terms for decision-making processes. I will develop this argumentation on the basis of two empirical studies conducted within the framework of two research projects. ${ }^{3}$

The concept of non-knowledge serves to highlight the fact that dealing with phenomena such as genetic anomalies in biomedical frames is not trivial but implies certain expert practices. Obviously, non-knowledge is - in contrast to frequently held beliefs - not necessarily functional for science. By differentiating the term, it will be made clear that non-knowledge implies various options for dealing with open questions such as further research or politicisation.

From a theoretical point of view the intention is to combine two completely different sociological discourses, the modernisation theory-oriented debate about boundary politics (Beck/Bonß/ Lau 2004) and the constructivist analysis of non-knowledge (Luhmann 1995). My aim is to develop a knowledge-sociological analysis of expert practice in the field of human genetics, critically assessing the competency claims of medicine. In the process I will introduce the German-language sociological debate on non-knowledge, since it has contributed considerably to sharpening this concept (section 2). ${ }^{4}$ On the basis of a typology of

\footnotetext{
3 The research project "Life-Politics in the Risk Society" (No. 8885) was supported by the jubilee fund of the Central Bank of the Republic of Austria (Oesterreichische Nationalbank) and carried out at the Institute for Advanced Studies, Vienna. The research project "Life Science in European Society" (QLG7-CT-1999-00286) was supported by the European Commission, DG Research; the Austrian case study was conducted at the Institute of Technology Assessment of the Austrian Academy of Sciences, Vienna.

${ }^{4}$ So far, the topic of non-knowledge has only been discussed in sociological observation of human genetics in the context of the frequently debated right to nonknowledge (Wehling 2003a). Against the background of expanding capabilities of predictive genetic diagnostics and possible discrimination dangers from employers and insurance companies, there has been a discussion since the 1980s of the extent to which an informal or formal right not to
} 
knowledge forms, I will argue that prenatally diagnosable disabilities transcend the defining categories of modern medicine. As a consequence, new differentiations and boundaries have to be found (section 3). The problematique of boundary politics is highlighted in the case of late term abortion. Legal and medical developments are accompanied by the blurring and reconstruction of boundaries by experts, though with a close link to societal guiding principles (section 4). Experts' taking into account of other knowledge forms and alternative ationalities (in counselling and in boundary politics) suggests that a reflexive type of expert could emerge. I argue, however, that these very practices contribute to the legitimisation of a medical genetic interpretation framework for prenatally diagnosable disabilities (section 5).

\section{Non-knowledge in the knowl- edge society}

According to the hypothesis that modern societies are becoming increasingly fragile, as put forward by Nico Stehr (2000), it is precisely because of the growing importance of knowledge in all areas of life and institutions that societal uncertainties and nonknowledge are coming to the fore. It would be an over-simplification to treat non-knowledge as a deficit that needs to be overcome. According to Helmut Willke (2002), knowledge in the knowledge society is, in view of uncontrollable systemic risks, ${ }^{5}$ consti-

have to know your own genetic predisposition can be founded and legally anchored. This discussion of non-knowledge, however, has taken place on the intentional level of "not-wanting-to-know" rather than on a functional level.

5 Systemic risks are new forms of risk which cannot be localised, or for which personal responsibility cannot be identified; they emerge from an 'interlinkage of risks' and usually result in a destabilisation of the system. Willke mentions the world tuted by expertise in the treatment of non-knowledge. Non-knowledge here is not characterised by a preliminary lack of knowledge, but by a fundamental uncertainty that cannot be eliminated (ibid.: 11). Willke's notion of 'crisis', therefore, refers to more than mere a loss of credibility or deficiency in knowledge. It signifies the inability to deal with non-knowledge in a competent way, because non-knowledge, being the other, complementary side of the coin of knowledge, has not yet been appropriated and made manageable (ibid.: 18).

The category of non-knowledge has also been systematically introduced into the sociology of science. Taking the example of high energy experimental physics, Karin Knorr Cetina (1999), for instance, describes a change in the epistemology of the natural sciences. After the objects of observation, due to their physical characteristics, have been turned into virtual objects and into products of an experimental machinery, scientists are forced to adopt a new methodological self-reflexivity. Obstacles to cognition, ambiguities, and thus the boundaries of knowledge come into the centre of the analysis. By making the diverse causes of systematic misjudgements part of the reflection, physics "has forged a coalition with the evil that bars knowledge, by turning these barriers into a principle of knowledge" (ibid.: 64). The 'simple' generation of knowledge is replaced by a process of specifying nonknowledge. In addition, the door is kept open for the production of positive knowledge.

The knowledge society presents itself as a society which is not just based on 'knowledge', but also - speaking in terms of systems theory - on the 'form' of knowledge, i.e. on a distinction (prior to the indication of anything specific) that equally includes non-

financial system and the Internet as nstances thereof. 
knowledge. ${ }^{6}$ Knowledge societies are therefore essentially characterised by the acute increase in the significance of non-knowledge: first, through the systematic production of nonknowledge, and second, through the forced societal management of nonknowledge. ${ }^{7}$

Even though the category of nonknowledge has only recently become a subject of systematic reflection and conceptual work (see Japp 1997; Wehling 2003b), the interest of sociology in this topic can be traced back to the point where controversies over risk and ecological crises indicated the limits of scientific knowledge. Consequently, early conceptualisations were developed with close reference to risk and uncertainty (Collingridge 1980; Wynne 1992; Funtowicz/Ravetz 1993). This aspect is still relevant. To date, conflicts over risk or technologies related to serious ecological and/or health damages have been the main subjects stimulating empirical analyses with a focus on non-knowledge. ${ }^{8} \mathrm{Al}$ though these analyses are grounded in incongruent basic assumptions, they agree that non-knowledge is not necessarily functional for scientific research any more: the basic assumption

6 For the notion of 'form', see Luhmann 1991: 23, 59-60.

7 From this perspective, technology assessment (TA) can be seen as an early attempt to achieve institutionalised anticipation of consequences, though under optimistic assumptions concerning their control. Accordingly, it is the expert who is the only one who knows about the limitations of scientific knowledge and the specification of non-knowledge (van den Daele 1996); boundary-drawing between knowledge and non-knowledge appears as a cognitive process. Against this background, the development of participatory TA (Joss/Bellucci 2002; Abels/Bora 2004) can be understood as an attempt to ensure that experts do not have sole responsibility for boundary-drawing.

${ }^{8}$ For the example of chemical policy see Böschen (2000); for the example of mad cow disease (BSE) see Dressel (2002), Japp (2002a). that non-knowledge would, inevitably, lead to new knowledge is now contested. Thus, non-knowledge is not primarily seen as a precondition for problem solving, a perspective advanced by Robert Merton (1987) with his notion of 'specified ignorance'. Merton argued that in order to generate new knowledge one has to specify non-knowledge, and was the first to emphasise the kind of non-knowledge that was functional for enabling further research. Forms of nonknowledge that could not be tackled were left aside.

The following discussion deals with the conceptualisation of non-knowledge within the two 'grand theories' in which it has become most relevant: the theory of reflexive modernisation of Ulrich Beck, and Niklas Luhmann's constructivist systems theory.

\subsection{The modernisation-critical posi- tion}

Beck (1996) refers to the notion of non-knowledge in order to distinguish his model of reflexive modernisation from alternative perspectives (e.g. Giddens 1990). According to Beck, it is not the mere accumulation and globalisation of knowledge that allows us to characterise modernity as 'reflexive', but rather the recognition of nonknowledge. Risks and dangers which emerge in the course of the process of modernisation must not, for the sake of the preservation of the status quo, become visible as systemically induced consequences of modernisation. Thus the struggle over the conditions of definition becomes vital for political reforms, together with the clarification of the boundary between knowledge and non-knowledge. ${ }^{9}$

\footnotetext{
${ }^{9}$ Giddens' theory of modernisation offers a somewhat different account; he links the reflexivity of modernity closely to the diffusion and circularity of expert knowledge. It is not non-knowledge that is the engine driving reflexive modernisation, but a conglomeration of different mechanisms which can be subsumed generally under global-
} 
According to Beck, in order to arrive at reflexivity it is necessary to gain knowledge about non-knowledge. Non-knowledge appears to be a confined area that is static and objectively 'given'. The complementary area of non-knowledge shares common features with his notion of risks as apparently objective and 'pre-discursive' threats posed by technology (Beck 1986). In other words, it appears to be independent in its existence of any knowledge conflicts (and therefore a priori to them), but dependent in its scope on current claims (and articulations) of knowledge. ${ }^{10}$ Insuperable and unforeseeable non-knowledge - in Beck's terms (1996: 302) a 'Not-beingable-to-know' ("Nicht-Wissen-Können") - does not have a systematic place in this perspective, and the causes and processes of the constitution of such non-knowledge are, in fact, of secondary interest. Given the assumption of the existence of a certain objectively available ('knowable') area of knowledge, the analysis has to focus on the suppression and omission of non-knowledge ('Not-wanting-toknow'; "Nicht-Wissen-Wollen"). This means that there is a danger of an intentional reduction of the problem of non-knowledge.

isation and the institutionalisation of knowledge (Giddens 1990). Thus, reflexivity appears as a general feature of modernity. With the development of an 'institutional reflexivity', consequences that are already potentially inherent catch up with modernity. Giddens, unlike Beck, does not postulate a structural rupture within modernity, and he does not need to provide empirical evidence of a transition towards a 'second' modernity. Compared to Beck, his rather linear model of knowledge of reflexive modernisation provides less opportunity for the endogenous precariousness of rationality to become apparent.

${ }^{10}$ In the end, such an epistemological realism assumes the 'accessability' of reality through observation; this is supported by the argument that it is precisely ignorance of, and the denial of knowledge about, the dangers to which industrialisation gives rise that lead to an increase in real dangers (Beck 1996: 311).
In his attempt to differentiate the categories introduced by Beck while avoiding the problems mentioned above, Peter Wehling (2003b: 124-126) distinguishes three dimensions of nonknowledge. First, he distinguishes known from unknown non-knowledge (criterion of knowledge). Here, nonknowledge refers to preliminary knowledge gaps and ambiguities, the deficient character of which is well known. In contrast, phenomena where it is still unclear that something is not known, or rather, what it is that is not known, are referred to as 'unknown non-knowledge'. Second, temporary non-knowledge is distinguished from permanent (enduring) non-knowledge (criterion of time). The question of whether non-knowledge is insuperable or resolvable, i.e. whether it is 'specifiable' in the sense of Merton and therefore open to further analysis, is especially important with regard to the acceptance and funding of research (Wehling 2004: 73). A third dimension of non-knowledge refers to the criterion of intentionality. This distinction between non-knowledge we are either aware or unaware of, with the latter being inevitable, is part of Beck's action-theoretical perspective. Nonknowledge is primarily seen as a consequence of individual action and decision-making (what could the actor have known? what should he have known?); thus, there are significant moral implications. ${ }^{11}$

Wehling's attempt to discuss the concept of non-knowledge, which still has insufficient empirical backing, with the goal of systematising it, is instructive. His comparatively thorough differentiation of the term is directed against the 'thin' typology suggested by systems theory (see below), and strives for the development of a comprehensive research programme. Ultimately, it aims to analyse the processes of emer-

\footnotetext{
${ }^{11}$ For instance, Wehling (2003: 126) refers to non-knowledge sustained in the face of better judgement.
} 
gence, communication and processing of non-knowledge. These concepts allow the reformulation (and an alternative discussion) of controversies about risk, and empirical case studies will indicate their descriptive potential (for a first step see Böschen 2002).

At the same time, Wehling's concept bears a certain resemblance to Beck's approach. Non-knowledge is conceptualised as the result of a process of construction and assignment, and at the same time non-knowledge refers to more or less objectively knowable phenomena, thus existing prior to (any) discourse. This becomes evident in Wehling's description of the hole in the ozone layer (2004: 75-79), where he analyses the transformation of nonknowledge with regard to the process of catching up with the explanations of already manifest consequences (triggered off by CFC). An implicit reference to Beck's realism of hazard runs the risk of, in principle, considering nonknowledge as a deficit that needs to be overcome. For hazards can only be averted with the help of knowledge; they grow without such knowledge. If non-knowledge remains associated in an ultimately essentialist way - with a knowledge deficit or "knowledge gaps" (Wehling 2004: 69), then we might lose sight of the fact that (non)knowledge results from contingent processes of construction, which can always take an alternative form - to be precise, in a way that is independent of real progress in knowledge.

\subsection{The constructivist position}

Although Luhmann's analysis of nonknowledge (1992) has its origin in ecological problems, it does not offer a criticism of institutions. Rather, the radical dimension of this kind of analysis results from its epistemological approach. In order to perform an observation, and hence to generate significance, the observer (in Luhmann's terminology) must focus on one side of the discrimination made which subsequently becomes relevant for any further operation. Concomitantly, an 'unmarked space' is being produced. As this is done, nonknowledge becomes a necessary constituent of any knowledge production. The accumulation of knowledge can, according to Luhmann (1995: 177), only result in a progressive reproduction of non-knowledge; there can be no gradual transformation of nonknowledge into knowledge. ${ }^{12}$

Japp (1997) follows this conceptualisation of non-knowledge. It has systematically developed the 'eigenvalue' of its object of research. Japp distinguishes, in a more pronounced way than Luhmann, between specific and unspecific non-knowledge. ${ }^{13}$ Specific non-knowledge corresponds terminologically to Beck's notion of 'Not-yetknowledge' ("Noch-Nicht-Wissen"). Yet unlike Beck, Japp (2002a: 43-48) places the emphasis on the systematic difference between facts and form of knowledge. Overcoming it is always an $x$ complishment of construction from the viewpoint of the observer; therefore, the question of connectability ("Anschlussfähigkeit") is paramount. Ambiguities can, on the one hand, be mitigated (with reference to particular value judgements) in such a way that non-knowledge is characterised as a cognitive problem rather than a trigger for political conflict. In this sense, specific non-knowledge is a form of non-knowledge that can be normalised on a medium-term basis and transformed into 'secure' knowledge,

\footnotetext{
${ }^{12}$ Apart from the constructivist description of non-knowledge, there are also 'realistic' points of reference in the systems theorists' approach. From this perspective, non-knowledge is seen as a product of complexity and therefore allocated on a factual level; see Willke (2002).

13 In fact, Luhmann (1995) distinguishes between specified ('marked') and unspecified non-knowledge. However, he does not look into the sociologically relevant questions of the circumstances under which either of the two kinds of non-knowledge is referred to, and what consequences follow from this.
} 
even if there is considerable disagreement amongst experts over the course of such a transformation. On the other hand, specific non-knowledge is a form of knowledge that refers to comparison or probabilities. Hence, it dlows us to bring out uncertainties and to ask for risk asessments. In other words: the specificity of non-knowledge is emphasised, while non-knowledge (as such) is highlighted - depending on the degree to which uncertainty is accepted and science and technology are trusted.

Unspecific non-knowledge is a construction which rejects the validity claims of (expert) knowledge as well as those of specific non-knowledge. It is a form of societal self-description in which uncertainty is labelled as potentially catastrophic. The reaction to such a 'potentiality of illimitable damage' is to demand 'avoidance behaviour', i.e. not to adopt certain available (technical) options. Unspecific nonknowledge, actually a form of not connectable non-knowledge (how should one speak about something that is simply unknown?), can only be asserted in a meaningful way through the communication of the 'catastrophe' as a symbol of what is to be avoided (Japp 2002b: 436). This is the case especially when new and unknown phenomena or developments are egarded as beyond the scope of scientific knowledge. This means that in principle, they transcend the explanatory potential of scientific knowledge, are considered unpredictable and uncontrollable with regard to science, and furthermore become, or are turned into, a potential threat. We can understand this process as a generalisation of non-knowledge.

The political consequences of this generalisation with regard to knowledge and technological conflicts are well known. The assignment of unspecific non-knowledge involves the danger, as Helga Nowotny (2005: 41-42) argues with regard to the loss of authority of experts, that laypersons re- nounce their loyalty to experts and consider taking the 'exit option'. They could abandon the discourse with scientific experts and 'cross over' to the political system: they could, by means of initiatives or demonstrations, influence science, legislation and the regulation of research.

One of the strengths of the constructivist position is that it helps to understand non-knowledge as a coproduced phenomenon and therefore as a logical necessity. The sociologically relevant questions, then, are how processes of acknowledgement of (non-)knowledge develop, and how claims of (non-)knowledge turn into (non-)knowledge. Following an important trend in science research one can ask, for instance, in which way a representational relationship is established between 'clean', decontextualised laboratory objects and the reality of nature (e.g. Latour 1999: chapter 2). Wehling's differentiated terminology is probably the best way of capturing such processes, if they can be captured at all.

Japp's strict constructivism, on the other hand, could overcome the perspective of a symmetrical relation between knowledge and non-knowledge (i.e. that acquiring knowledge should inevitably be linked to reducing nonknowledge). Due to the absence of a privileged observer position, assigning something to knowledge or nonknowledge is, in the end, a normative decision. Non-knowledge is therefore a construction that leaves open every political option. In some situations, and in the view of those who look sceptically at a plan or project (for whatever reason), the readiness to acknowledge non-knowledge is so low that critics and whistleblowers can easily prevail. In other situations, there is no communication about nonknowledge or rather non-knowledge is communicated as uncertain knowledge or knowledge not yet established, irrespective of any perceived advance in knowledge. 
Finally, from such a perspective nonknowledge appears less as a cognitive but rather as a social phenomenon. A certain way of communicating, in the case of unspecific non-knowledge often associated with the (aggressive) claims of persons affected (Japp 1999: $30)$, is taken as a certain way of ${ }^{\infty}$ signing non-knowledge. As a result, conflicts not necessarily centred around ecological risks also become accessible to the category of nonknowledge. The following investigation of prenatal testing uses this perspective.

\section{Prenatal testing, its develop- ment and its relevance}

Prenatal testing and genetic counselling span the fields of human genetics and medicine. While prenatal testing in the early 1970s was merely a sideline for human geneticists, it has since differentiated itself from the field of human genetics, become successfully institutionalised, and now, as part of gynaecology, is considered a core aspect of pregnancy care (Nippert 1991). ${ }^{14}$ In 1966 the first cultivation of foetal cells suspended in amniotic fluid was successful. This was seen as a decisive step towards the cytogenetic and biochemical detection of foetal anomalies. The first prenatal detection of Morbus Down was performed in 1968.

While prenatal testing is not restricted to DNA analyses (in fact the majority of examinations employ ultrasound), prenatal testing has now become an important field of activity for genetic counselling. Current figures show this.

\footnotetext{
14 Prenatal testing includes examinations and tests relating to the development of the foetus over the course of pregnancy. Ultrasound is the most common form of non-invasive prenatal testing. In addition there are invasive diagnostics, i.e. surgical interventions which sample cells from the unborn child and test them, mostly for Down's syndrome (amniocentesis, chorionic villus sampling).
}

In 1970, when prenatal testing was introduced in Germany, only six amniocenteses were registered. ${ }^{15}$ Shortly thereafter prenatal testing was added to the catalogue of services provided by compulsory health insurance and already by the mid-1980s (in the meantime chorionic villus sampling (CVS) had been introduced) over 30,000 amniocenteses and 3,000 CVS were registered. ${ }^{16}$ In 1999 alone approximately 70,000 invasive examinations were performed. This means that roughly every tenth pregnancy involved invasive diagnosis (Nippert 1999).

An important factor in this normalisation process was the way in which various court decisions obliged doctors to promote the potential of prenatal testing to women over the age of 35. Hennen et al. (1996: 78) state that prenatal testing has almost become a standard examination in pregnancy care for women over 35. While prenatal testing is still ethically controversial, it is predominantly directed towards the early detection of Down's syndrome, and is currently the only way of preventing the birth of disabled children.

\subsection{Transgressing traditional catego- ries}

In the case of prenatal testing, the consequences of an ongoing scientification process make it necessary to draw boundaries. Recently, Ronald Hitzler and Michaela Pfadenhauer (1999: 99) have pointed to the fact that

\footnotetext{
${ }^{15}$ Amniocentesis involves removing amniotic fluid in the 16th to 18th week of pregnancy by means of transabdominal puncture of the uterus. Foetal cells from the amniotic fluid are cultured and analysed in the laboratory, mostly for chromosome anomalies such as Down's, Klinefelter, and Turner syndrome.

${ }^{16}$ CVS involves removing chorionic tissue (a preliminary stage of the placenta genetically derived from the foetus) by means of a needle inserted through the abdominal wall or vagina. As with amniocentesis, chromosomes (or DNA) can be analysed.
} 
improved techniques for diagnosis have resulted in precarious data acquired at a very early point in time, which transcend the way of coding (and separating) 'healthy' and 'sick', a constitutive element of modern medicine. $^{17}$ Our case supports this notion. With the help of early prenatal testing (e.g. measurement of the nuchal translucency thickness ${ }^{18}$ ), certain distinctive features considered to be reliable indicators of the Down's syndrome (socalled 'soft-markers') can be diagnosed as early as the tenth week of pregnancy. While Down's syndrome constitutes a chromosomal aberration and as such, with regard to the genetic paradigm (related basic analysis: genetically normal/abnormal), an abnormality, it is difficult or impossible for the prenatal diagnostician to identify its 'clinical implication', in other words its 'meaning', with regard to the medical code (healthy/sick). In practice, it is obviously difficult for the expert to determine medically operationalisable criteria to decide whether an abortion

17 According to the medical code, in Luhmann's (1990) terminology, disease represents the positive side of the distinction as it is operationally connectable and therefore corresponds to the 'goal of $x$ tion' or the teleology of the system. The fact that human genetics establishes a new dichotomy, so to speak behind the back of medicine, is a development Luhmann was aware of. Health is differentiated by the introduction of the new categories 'genetically burdened/not burdened'. However, Luhmann confined himself to perceiving the interdependency between basic coding and (genetically induced) secondary distinction as a proof of the stable autonomy of the medical system. It remains, however, unclear how this secondary distinction is practically operationalised and what the consequences are. In the end, a reasonably unconflictual interdependency of the two codings has quite a few preconditions; all complexity associated with the diagnosis of 'being genetically burdened' has to be countered by discharge mechanisms ("Entlastungsmöglichkeiten") within the logic of the medical system.

18 This measurement is an ultrasound evaluation of the thickness of the neck fold of the foetus. after prenatal testing is egitimate or not. The following interview passage illustrates the practical difficulties involved:

It is ethically unproblematic if my prenatal diagnosis is anencephalus ${ }^{19}$; I spare the woman a pregnancy, including the risks of a pregnancy, and the child anyway has no chance of survival (...) It is more tricky in the case of $v$ able deformations; because here, of course, at some point the question arises, how disabled does a child have to be that I categorise it as ethically justifiable to seriously consider the early diagnosis, so that I can perform an abortion/kill it? (1:17/41:52)

Within the continuum of viable disabilities (quantitatively) accounting for the major part of prenatal testing, it is obviously difficult, on the basis of medical knowledge, to provide 'trigger points' unconditionally linked $b$ certain strategies of action, unless the diagnosed deformations or genetic defects can be reformulated within the traditional categories of medicine so that they become unambiguous. This is the case with anencephalus, because it is described as a kind of deformation not allowing life after birth. In this case it is the distinction alive/dead that, as a distinguishing criterion, provides orientation and relief with regard to the decision taken.

The difficulty of boundary-drawing by means of expert knowledge becomes apparent from the fact that the expert does not pursue, and does not try to operationalise, the question of when it starts to be 'tricky' to perform prenatal testing. The social consequences of such a blurred boundary can be observed on the level of interactions. Last but not least, in view of professional codes regarding genetic counselling, it can be said that for such a decision it

\footnotetext{
${ }^{19}$ Severe deformations in the central nervous system, caused by a defective closure of the neural tube in the development of the foetus; babies lack the skullcap and substantial parts of the brain.
} 
is obviously no longer sufficient to refer to expert knowledge alone. Accordingly, the norm-setting, goaloriented, hierarchically structured consultation of an expert is not considered appropriate any more..$^{20}$ Against this background, it becomes understandable why the unprejudiced, process-oriented and client-centred ideal of counselling has become so popular, as it is easily reconcilable with the central value of modern medical practice, i.e. the autonomy of the patient. ${ }^{21}$

\subsection{A typology of non-knowledge}

I shall now relate the blurring of boundaries to some arguments from the sociology of knowledge. On the level of different forms of knowledge, we can essentially distinguish three categories: ignorance, uncertainty, and non-knowledge.

a) Ignorance refers to an inadequate or preliminary form of knowledge that has the potential to be corrected. Practically, it is about mistakes, errors and false statements that can subsequently be clarified, for instance by empirical data or through a critique of science or ideology. From a sociological point of view, this level is of secondary importance.

b) Uncertainty, or uncertain knowledge, is located on a cognitive level. As already mentioned, two forms of uncertainty can be distinguished with regard to human genetics: diagnostic uncertainty (what is the probability of

\footnotetext{
${ }^{20}$ A corresponding plea for non-directive forms of counselling, which provide extensive medical-genetic information supporting individual decision-making, can be found, for example, in GfH (1996). For a criticism of the ideal of non-directivity in counselling methodically grounded in participant observation of counselling interviews, see Bosk (1992).

${ }^{21}$ From the perspective of human genetic counselling, see Reif/Baitsch (1986). A summary with regard to the changing concepts of counselling from the perspective of discourse analysis is provided by Waldschmidt (1996).
}

a disease on the basis of genetic disposition?) and prognostic uncertainty (when will a disease appear and how will it develop?).

Uncertainties related to indication and diagnosis play a crucial role with regard to prenatal testing. In the frame of early prenatal testing (e.g. measurement of the nuchal translucency thickness), the woman gets a 'risk figure', an expression of the individual probability of giving birth to a disabled child (for example: 'you have a risk of 1 in 500'), rather than a definitive assessment of the genetic status of the child. ${ }^{22} \mathrm{~A}$ traditional yes/no diagnosis is replaced by a statistical calculation. Not 'healthy' or 'not healthy', but probably healthy, but maybe not healthy. Whether a probability of 1 to 500 means healthy or sick is ideally left to individual interpretation.

These kinds of uncertainty can be associated with the notion of specific non-knowledge, because they have a strong emphasis on cognition. At the moment there are no ways of transforming this uncertainty into knowledge, but there is precise knowledge about the kind of deficient character of this knowledge and thus usually an idea of how non-knowledge can be translated into knowledge on a medium-term basis. This form of knowledge is therefore in principle characterised by connectability ("Anschlussfähigkeit"). In practice, this means that there is confidence in being able to overcome, at least on a medium-term basis, the preliminary character and the ambiguity of knowledge with the help of additional and more extensive information, more precise measurements and tests, better qualified spe-

\footnotetext{
${ }^{22}$ In terms of probability the calculation of risks includes, on the one hand, the statistical basic risk correlated with the age of the woman. The variation, i.e. the individual specification of risk, results from the measurement of the nuchal translucency thickness.
} 
cialists, and so on. ${ }^{23}$ However, the people affected may perceive uncertainty as a fundamental and irreducible problem. But even in this case (of ascription of risk) the problem is framed as having the 'right configuration', i.e. it is not perceived as a problem that would transcend the professional frame of interpretation and relevance.

c) Non-knowledge: it is crucial for my argument that the notion of nonknowledge is not defined in a cognitivist way (i.e. as a problem of inadequate knowledge progress), but rather related to the level of social action. The notion of non-knowledge correlates to disabilities that can be discovered by prenatal testing and that are supposed to transcend bio-medical possibilities of interpretation. From this perspective, non-knowledge is characterised by the fact that expert knowledge is unable to 'grasp' the specific phenomena; it cannot really assess their significance. This should not be understood in the sense that prenatal testing would be incapable of understanding what is 'constitutive' of disability. The argument that medicine can no longer claim objectivity as a reference for its practice is not an epistemological one. It is a sociological argument: with regard to certain disabilities, medicine obviously can no longer refer to the kind of objective meaning which would normally result from the close link between expert knowledge (diagnosis) and decision (treatment), and which finds expression in the stable character of the distinctions healthy/sick and normal/abnormal. The practical implications for action described above are the result. In the context of claims of being affected, this problem can entail the radical negation of medical knowledge claims (Japp 2002a: 47).

\footnotetext{
${ }^{23}$ Against this background, the attempt to isolate foetal cells from the mother's blood in order to get early and reliable evidence about forms of trisomy (Hahn/Holzgreve 2001) implies the perpetuation of a particular research logic.
}

If we agree with Luhmann that the constitution of knowledge is the result of a successful ascription of necessarily ambivalent information to a supposedly secure knowledge (and nonknowledge is therefore a 'construction defect'), the analytic benefit of the terminology introduced becomes somewhat clearer: due to its ambiguity, disability leaves open several options of ascription. By referring to hegemonic discourses and cultural values it can, for instance, be clarified in a way that identifies non-knowledge as a cognitive problem (consequence: demand for more precise test results, better therapies etc.). In this case, nonknowledge becomes framed as uncertainty. Alternatively, by referring to different discourses and alternative value orientations, the ambiguity attached to disability can also become effective as a tool for the repulsion of scientific claims of cognition. In this case non-knowledge is not connected to the option of continuing scientification, but is opened up to external criticism - with politicisation as a consequence.

Taking the institutionalisation of prenatal testing in to consideration, one can ask which discourses, norms and rules would help to normalise the understanding of professional practice as an appropriate configuration of the problem. In what follows, I will analyse the rationality of concrete boundary-drawings in order to reconstruct these discourses and norms.

\section{The politics of boundary- drawing}

Modernisation theory sees boundarydrawing as essentially related to the postulate of boundary blurring ("Entgrenzung") of institutions and guiding principles. From this perspective, "Entgrenzungen", i.e. the dissolution or pluralisation of categorical distinctions (Viehöver/Gugutzer/Keller/Lau 2004), are regarded as indicators of the emergence of a 'second' modernity. 
According to Beck et al. the epochal rupture consists of the fact "that the guiding ideas of western modernity have become questionable because of the dynamics of secondary effects" (2001: 25). The category of boundarydrawing becomes interesting for the theory of modernisation for one main reason: because of its strong hypothesis of an epochal rupture, the theory is highly dependent upon criteria for empirical testing. A central argument is that modernity is reflexive from the moment when, as a consequence of scientific and technical developments, habitual boundaries and patterns of thinking are dissolved by means of risks and dangers released by (and in) the process of modernisation. Such boundaries as the difference between nature/society, life/death, or healthy/ sick Niehöver 2005) are fundamental to the self-understanding of modernity, because they constitute action and decision-making resources as well as mechanisms for assigning responsibilities.

From this point of view, boundary work provided by the experts is therefore regarded as an expression of an institutional dynamic, but not as a form of strategic management of symbolic boundaries such as Gieryn (1983) would propose. ${ }^{24}$ His concept of 'boundary work' focuses on the way science appropriates, by means of boundary work, resources related to the privileged position of science, such as credibility, prestige and power (Gieryn 1995). Finally, the scope of the autonomy of science needs to be maintained and science needs to be protected from external control, for

24 Gieryn (1983: 782) characterises the boundary work of scientists as 'ideological efforts'. The way he poses his main question, "What images of science do scientists present to promote their authority over designated domains of knowledge?" (ibid.: 783), indicates that he understands the ideology (of 'scientificality') as an active and strategic process of establishing boundaries. example by delimitating it from other functional systems such as policy.

The boundary-drawing discourse of human genetics can therefore be studied from at least two perspectives. On the one hand, boundary construction by experts can - with regard to political and ethnic conflicts - be seen as a strategy designed to legitimise professional authority (see CunninghamBurley/Kerr 1999; Bogner 2004). Modernisation theory, on the other hand, chiefly considers the way experts deal with the opening up of the scope for decision-making, a field which is subject neither to traditional claims nor to formal regulations.

The boundary work of experts can be illustrated by taking the urgent problem of late term abortion as an example. The reconstruction of the rationality underlying boundary construction in this case can inform us about the discourses and value orientations that enable experts to provide and implement the authoritative notions and concepts for the interpretation of disabilities to be discovered by prenatal testing; the legitimisation of decisions; and, thus, the societal debate about disabilities.

\subsection{Late term abortion: the prenatal boundary between life and death}

Advances in neonatal medicine have contributed to rendering the prenatal line between life and death more fluid. This has become especially problematic with regard to the recently amended German abortion law. In the course of the 1995 amendment the temporal limitation for an abortion previously set at the $22^{\text {nd }}$ week (orientated towards the boundary of viability) was eliminated. In principle, in case the foetus is classified as a hazard' to the physical or mental health of the pregnant woman, the doctor may induce an abortion (if the pregnant woman consents) up until shortly before birth (StGB § 218a, section 2). The situation in Austria is similar with respect to the penal code. According to 
Austria's abortion law (in force since 1975), an abortion based on eugenic indications may be conducted up until shortly before birth (StBG $\S 97$, section 1 , item 2).

The dssolution of a definitive, albeit pragmatic demarcation presents a serious challenge for a gynaecologist. Performing an abortion between the $22^{\text {nd }}$ and the $24^{\text {th }}$ week of pregnancy, ${ }^{25}$ at a time when the child is generally considered viable, can get doctors into a difficult situation with serious consequences. ${ }^{26}$ Obviously, an absurd and irreconcilable dilemma arises if a (nonpunishable) abortion makes necessary to perform an act of active euthanasia in order to pursue the original intention. On the other hand, it is obvious that the need to take such decisions tends to result in a practice which is regulated by experts themselves.

With regard to the exigency of having provisional-moral boundary constructs (Beck/Bonß/Lau 2004: 15), referring to a viability boundary as a criterion of a time limit for late term abortions (as suggested for example by chamber of medical doctors in BÄK 1998) does not help in the individual case. Firstly, this threshold is fluid as a result of advances in neonatal medicine, and of course it varies in individual cases. Finally, the actual week of pregnancy cannot even be determined with absolute accuracy. Hence, boundaries keep

${ }^{25}$ A late term abortion in practice essentially means the inducement of labour in anticipation that the child will be stillborn. In some cases a so-called foetocide is performed in order to be sure. Prior to the abortion, the foetus is killed by means of a potassium chloride injection to the heart.

${ }^{26}$ In Germany around 1,500 abortions are performed annually after the 22nd week of pregnancy, according to an article in the German magazine "Der Spiegel" (Friedrichsen/Ludwig 1999). The Federal Agency of Statistics reported 190 abortions in 1997, but the director of the Hospital Doctors' Association of the Marburger Bund, Frank Ulrich Montgomery, estimates approximately 800 late term abortions per year (Sperber 2001). dissolving as it is no longer possible to discern, based on medical diagnostic methods, on which side of the border one stands at a concrete point in time. But even if one disregards ambiguities and the need to interpret viability criteria there must be exceptions, either due to medical or eugenic indications or in cases when, for example, the results of an amniocentesis are received very late. Hence prenatal diagnosticians and gynaecologists are faced with the problem of having to redraw the prenatal line between life and death. Ultimately, the boundary construction provides an immediate guideline for professional action and decision-making. For us, as a result, the ensuing question relates to the interpretations and considerations supporting these boundary constructions.

\subsection{The pluralisation of the life/death distinction}

The prenatal boundary between life and death, prior to its dissolution over the course of the abortion reform, had been drawn by the law - which itself was orientated toward medical 'facts' ('the boundary of viability'). For us this raises a new and interesting question, namely how scientific, judicial or philosophical knowledge plays a role in the reconstruction of this boundary. In any case, the problem of late term abortions is no longer regulated by formal law but rather by the informal boundary politics of experts. It is the experts who are formulating processes for dealing with this problem in publications (e.g. von Kaisenberg/Jonat/Kaatsch 2005), in directives and statements of professional associations (e.g. DGGG 2003), at symposiums and congresses, and also on the level of day-to-day internal cooperation and team meetings in hospitals. This subpoliticisation, however, is not tantamount to an exclusive orientation towards medical genetic expertise. In the following it will be shown that ethical or philosophical knowledge is 
also of significance for the reformulation of boundaries.

It is possible to reconstruct the logic of boundary-drawing in expert discourse based on its discussion of exceptional cases. Two different argumentation types have been analytically identified in connection with the manner in which experts classify exceptional cases. On the one hand, there is an effort to fall back on medical criteria as a way of drawing a boundary. This means that the legitimisation of late term abortion is founded on a poor survivability prognosis for the foetus. By referring once again to viability in this way the pragmatic boundary of the former abortion law is more than just revived, since this criterion may also now be applied to the period after the $22^{\text {nd }}$ week of pregnancy when decisions are still possible. 'Non viable deformities' or 'untreatable diseases' consequently represent legitimate exceptional cases for late term abortions according to the experts I questioned asked. In an attempt to concretise such terms when they need interpretation, experts tend to draw on the medically most clear-cut cases. A concrete example is anencephalus which, based on a very low survival probability, is characterised by experts as a 'death-like' condition. In such a case the continuation of the pregnancy is usually deemed pointless or an unnecessary risk for the woman. The diagnosis 'anencephalus' is therefore associated with the demarcation dead/alive. Ultimately in this type of argumentation, the distinction between life/death is in a way reintroduced on the side of life (i.e. in the time period open to decision-making, starting with the viability boundary). In view of the interpretational dependency of the exceptional case, this can be viewed as a pluralisation of the demarcation.

The second type of argumentation may also be considered a pluralisation of the demarcation, but in a stronger sense, since a rationality different than that of medicine has a bearing. In this case experts do not legitimise late term abortions according to the life/death distinction set out above. Here, the boundary-drawing which becomes action-orientative for a problematic case beyond the viability boundary, refers to the distinction between personal and non-personal life. Further elaborated, this distinction provides the basis for the bioethical debate which ties granting the right to life to the criterion of personhood (e.g. Tooley 1979; Singer 1979). The following interview passage serves to illustrate this second argumentation type, and sums up the argument in a very reflexive way.

Expert (E): I think Prof. $N$ and I both found a rather sensible solution to the problem of late term abortions here in the department. (...) We have a formulation that we draw a line starting with the $23^{\text {rd }}$ plus $0^{\text {th }}$ week. In other words, the beginning of the $24^{\text {th }}$ week and thereafter - and that is now the formulation of $\mathrm{T}$. from $\mathrm{A}$. - the confidence in prenatal testing on the one hand, and a considerable lack of cognitive development on the other must be very likely. Yes? Well, if you start at the end of the spectrum: anencephalus. There's no gestation age limit for anencephalus.

Interviewer (I): Spina bifida? ${ }^{27}$

E: No. Well, spina bifida must be diagnosed with much care. If associated with a large hydrocephalus, then yes, this is precisely a case in which one has to consider this formulation.

I: So what exactly is considered a severe cognitive defect?

\footnotetext{
${ }^{27}$ A congenital deformity of the spine and spinal cord ('cleft spine') which can appear in very different degrees of severity. Disorders accordingly range from slight impairment of the ability to walk to paraplegia with bladder and intestinal dysfunctions. Most of the time spina bifida is associated with hydrocephalus (excessive accumulation of cerebrospinal fluid within the cranium).
} 
E: Well. Yes, I have the formulation of personhood which is used in philosophical writing. Also, someone lacks a consciousness of his own existence, no feeling of past and future and no interaction with others. That would be the criteria of personhood, and there are such children. That can be operationalised up to a certain point.

I: So that can really be operationalised?

E: Yes. Yes, that can be operationalised. So when it's clear that this child will never be able to have interaction with a counterpart, whether from a philosophical or theological point of view, it will not develop a consciousness of its own self, it will not develop a consciousness for the past or future, or for any other perspective, then, well.... (2:113/632:677)

This second argumentation type can be considered reflexive in as much as the fiction of a clear possibility of differentiation is dismissed by means of the viability criterion. Diagnoses come to the fore (e.g. spina bifida) which are ambiguous, and which remain hidden in the first argumentation type and then must be decided ad hoc in practice. The professional orientations to action as doserved in the second case are directed toward criteria founded in ethics rather than medicine. In the end an effort is made to solve the problem of drawing the line by referring to ethical rather than medical categories. By means of the term personhood, mankind is divided into purely biological life forms and persons characterised by autonomy, rationality and selfawareness. For the legitimisation of a late term abortion this essentially boils down to the distinction between a dignified and undignified life (although not from a perspective with a eugenically objectified 'worth living' orientation). The terms autonomy and selfawareness thereby entail specific demands for actively shaping the individual's life through anticipation and acts of choice (Rose 1998). As general principles of governing the individual's life in late modernity these terms constitute, in such a perspective, guiding principles of society. In the bioethical concept of personhood, these guiding ideas essentially support a logically consistent convergence on a universal concept for the valuation of life.

The question of the (by no means unproblematic $^{28}$ relationship between bioethical discourse and societal notions of normality becomes important in the light of the general question of the significance of normality concepts for professional actions and decisionmaking. Beyond the present context, one can ask which framework of action, for example an expert lacking the pertinent training in bioethics, when forced to make a decision. According to the perspective developed here, it will be a framework of action which has been delimited in a logically consistent manner by bioethics and centred on the guiding principle of autonomy. Since - in line with the liberal school of bioethics - moral imperatives are developed from the hegemonic value system of society and the normative is strictly anchored in the empirically observable (Braun 2000: 108-135), the bioethical discourse must be understood as an expression as well as an elaboration and generalisation of societal normality concepts that are crystallised in the fundamental questions: What is a life worth living? What is a human being?

\section{Conclusion and outlook: re- flexive experts?}

Prenatal testing is marked by scientifically technical dynamics which un-

\footnotetext{
28 The logically compelling argument of utilitarians for permission to kill newborn babies (since a newborn can never be a person) will meet with resistance from the population. However, it is precisely the stringency of analytical operations which suggests, with the reference to normality, a need to adapt biopolitical norms and regulations in a way that would result in the liberalisation of contra-intuitive practices.
} 
dermine the stability of institutionalised decision-making conventions. Decision and design necessities for experts result from the evolving ambiguities of categorical definitions (healthy/sick, life/death) which require new boundary constructions. Specific professional orientations to action have been reconstructed here by analysis of these constructions. In the process it became clear that concrete professional orientations to action draw their cognitive-oriented and legitimising power from the implicit reference to society's guiding principles and notions of normality. These societal guiding principles operationalise themselves, according to the example of the more or less subpolitical regulation of late term abortions, in the form of a certain ideal of rationality. Categories such as autonomy, interactivity or self-awareness together make up the differentiation between person/non-person, a complement to the blurred life/death distinction. Admission into a social community therefore no longer depends on biological but on cognitive criteria, which require a minimum command over oneself as a precondition for a life worth living.

But the revaluation of an impartial, process-oriented and client-centred counselling ideal, which is centred around the guiding principle of individual decision-making autonomy, also illustrates the close link between professional practice and society's guiding principles. In connection with the problem of boundary drawing, this revaluation can be regarded as an $\mathrm{n}$ dication that the reference to expert knowledge no longer appears sufficient for the reformulation of prenatally diagnosable disabilities in the medical code, nor for the distinction between legitimate and non-legitimate practice as a consequence. On the level of discourse, the hegemony of a liberal autonomy principle seems to be expressed in the counselling ideal which has become the guiding principle for the regulation and handling of 'life and death questions' in the context of (bio-)medical progress. ${ }^{29}$ According to Erwin K. Scheuch (2003), in the light of this close link between professional action orientations and society's guiding principles it would be conceivable to speak of the "meaning of the spirit of the age for medicine".

Far-reaching conclusions follow considering the non-knowledge problem mentioned earlier. The concept of nonknowledge has been linked with prenatally diagnosable disabilities because it can be, and is in practice, associated with transcending in principle the scope of interpretations of medicine. Hence, non-knowledge as a 'phenomenon of asignment' is based on the legitimacy of the scientific interpretational framework. This conception analytically sensitises us to the question of which factors contribute to making 'objects to be dealt with' kgitimate objects of research practice.

Regarding the institutionalisation and normalisation of prenatal testing (as described), one can assume that the reference to society's guiding principles is a factor both in boundary politics and in the redesign of the counselling process. This factor is dysfunctional for a broad challenge to knowledge claims or for formulating a general suspicion of irrelevance. Provided experts draw boundaries conforming to norms and their decisions largely correspond to the expectations of society concerning what is acknowledged as their job, what is considered worth knowing and possible to say, and which taboos exist, ${ }^{30}$ non-knowledge

\footnotetext{
29 From the range of existing bioethical literature, the following sources can be cited as theoretically elaborated and influential in practice: for a pragmatic perspective Beauchamp/Childress (1994), and for more general accounts Harris (1991) and Charlesworth (1993).

${ }^{30}$ Not only eugenic practices and valueattributing counselling are taboos. An important taboo which cannot be further elaborated here is the application of prena-
} 
is not communicated. Consequently, professional authority (as defined in section 1) does not need to be called into question. ${ }^{31}$ Non-knowledge remains a cognitive problem and not a reason for politicisation. Hence, nonknowledge is not necessarily dysfunctional for science; however, it is not per se functional, a point Merton has already captured in his interpretation of a necessary 'specification'.

In view of the self-relativisation of experts in the course of the revaluation of client-oriented counselling or the experimental raising of ethical aspects within the field of prenatal testing, one can now ask whether we can observe a reflexive type of expert emerging in the case of human genetics, as May and Holzinger (2003) have suggested. They argue that, as a special field in medicine, human genetics with its aetiology and improved diagnostic techniques transcends the established paradigms and principles of medical knowledge. Experts are forced to communicate uncertainty, which makes the relevance of human genetic knowledge appear questionable to the client and is therefore dysfunctional for the medical monopoly on interpretation and for expert status (ibid.: 105). The revaluation of a layperson's perspective in genetic counselling, i.e. the tendency to dissolve the traditional dichotomy between experts and laypersons, can be interpreted as reflexi vity on an institutional level. The taking into account of the blurring of the distinction healthy/sick in professional practice indicates the cognitive level of the reflexivity criterion.

From a sociology of science perspective which focuses on the underlying

tal testing for sex determination (GfH 1990).

31 The expert practices mentioned cannot be equated with strategic intentional $\mathbb{~}$ tion. In fact, my analysis was guided by the assumption that certain practices and demarcations can be read ex post as functional for the legitimacy of professional authority. rationalities of counselling and the decision-making process, reservations are certainly in order concerning the hypothesis of reflexivity. In today's reality the expert in fact no longer has the power to make decisions and issue directives. However, in the context of the interpretation presented here, the (undoubted) dissolution of asymmetrical interaction relationships in genetic counselling must be read differently than as a reference to the contours of a reflexive modernity. A larger degree of autonomy indeed signifies a loss of professional authority pretending to offer socially binding solutions to problems. This, however, does not amount to a loss of relevance for expert knowledge. The expert who sees himself as an impartial and clientoriented information provider, and whose decisions and demarcations are ultimately structured based on hegemonic concepts of normality, does not seem questionable; if anything, the opposite is the case. His knowledge, his terminology and his profession are instrumental in the prenatal debate about the phenomenon of disability. The problem awareness and reflection of laypersons cannot be separated from the sensitisation by the criteria and categories which are significantly influenced by medical expertise. Hence, the expert has the power to decide who and under what conditions is allowed to participate in the decision-making process and which terms will be used in that process.

From this perspective, reflexivity would require the possibility of dealing with the experts' interpretation schemes and definitions of relevance in a reflexive way to be structurally embedded in the context of pregnancy care, for example in the form of an institutionalisation of alternative forms of knowledge in the counselling process. 


\section{References}

Abels, Gabriele/Alfons Bora, 2004: Demokratische Technikbewertung. Bielefeld: transcript.

Beauchamp, Tom L./James F. Childress, 1994: Principles of Biomedical Ethics. New York: Oxford University Press.

Beck, Ulrich, 1986: Risikogesellschaft - Auf dem Weg in eine andere Moderne. Frankfurt/M.: Suhrkamp.

Beck, Ulrich, 1996: Wissen oder NichtWissen? - Zwei Perspektiven "reflexiver Modernisierung". In: Ulrich Beck et al. (eds.), Reflexive Modernisierung - Eine Kontroverse. Frankfurt/M.: Suhrkamp, 289- 315.

Beck, Ulrich/Wolfgang Bonß/Christoph Lau, 2001: Theorie reflexiver Modernisierung - Fragestellungen, Hypothesen, Forschungsprogramme. In: Ulrich Beck/ Wolfgang Bonß (eds.), Die Modernisierung der Moderne. Frankfurt am Main: Suhrkamp, 11- 59.

Beck, Ulrich/Wolfgang Bonß/Christoph Lau, 2004: Entgrenzung erzwingt Entscheidung: Was ist neu an der Theorie reflexiver Modernisierung? In: Ulrich Beck/Christoph Lau (eds.), Entgrenzung und Entscheidung: Was ist neu an der Theorie reflexiver Modernisierung? Frankfurt/M.: Suhrkamp, 13-62.

Böschen, Stefan, 2000: Risikogenese. Prozesse gesellschaftlicher Gefahrenwahrnehmung: FCKW, Dioxin, DDT und Ökologische Chemie. Opladen: Leske + Budrich.

Böschen, Stefan, 2002: Risikogenese Metamorphosen von Wissen und Nichtwissen. In: Soziale Welt 53, 67-86.

Bogner, Alexander, 2004: Kritik der LifePolitics - zum Grenzziehungsdiskurs der Humangenetik. In: Österreichische Zeitschrift für Soziol ogie 29, 49- 71.

Bosk, Charles L., 1992: All God's Mistakes. Genetic Counseling in a Pediatric Hospital. Chicago: The University of Chicago Press.

Braun, Kathrin, 2000: Menschenwürde und Biomedizin - Zum philosophischen Diskurs der Bioethik. Frankfurt/M.: Campus.

Bundesärztekammer (BÄK), 1998: Erklärung zum Schwangerschaftsabbruch nach Pränataldiagnostik. In: Deutsches Ärzteblatt 95, A- 3013-3016.

Castells, Manuel, 1996: The Rise of the Network Society. The Information Age: Economy, Society and Culture, Vol. I. Oxford: Blackwell.

Charlesworth, Max, 1993: Bioethics in a Liberal Society. Cambridge: Cambridge University Press.

Collingridge, David, 1980: The Social Control of Technology. New York: St. Martin's Press.
Cunningham-Burley, Sarah/Anne Kerr, 1999: Defining the "social"- towards an understanding of scientific and medical discourses on the social aspects of the new human genetics. In: Peter Conrad/J onathan Gabe (eds.), Sociological Perspectives on the New Genetics. Oxford: Blackwell, 149- 170.

Deutsche Gesellschaft für Gynäkologie und Geburtshilfe (DGGG), 2003: Schwangerschaftsabbruch nach Pränataldiagnostik. München < abrufbar unter: www.dggg.de>.

Dressel, Kerstin, 2002: BSE - The New Dimension of Uncertainty. The Cultural Politics of Science and DecisionMaking. Berlin: Sigma.

Friedrichsen, Gisela/Udo Ludwig, 1999: Scheußliches Problem. In: Der Spiegel Nr. 27, 34-35.

Funtowicz, Silvio/Jerome Ravetz, 1993: Science for the post-normal age. In: Futures 25, 739-755.

Gesellschaft für Humangenetik (GfH), 1990: Erklärung zur pränatalen Geschlechtsdiagnostik. In: Medizinische Genetik 2, 8.

Gesellschaft für Humangenetik (GfH), 1996: Positionspapier der Gesellschaft für Humangenetik. In: Medizinische Genetik 8, 125-131.

Giddens, Anthony, 1990: The Consequences of Modernity. Cambridge: Polity Press.

Giddens, Anthony, 1991: Modernity and Self-Identity - Self and Society in the Late Modern Age. Stanford/CA: Stanford University Press.

Gieryn, Thomas F., 1983: Boundary-work and the demarcation of science from non-science: Strains and interests in professional ideologies of scientists. In: American Sociological Review 48, 781795.

Gieryn, Thomas F., 1995: Boundaries of Science. In: Sheila Jasanoff et al. (eds.), Handbook of Science and Technology Studies. Thousand Oaks: Sage, 393443.

Harris, John, 1991: The Value of Life. An Introduction to Medical Ethics. London: Routledge.

Hennen, Leonhard/Thomas Petermann/ Joachim J. Schmitt, 1996: Genetische Diagnostik - Chancen und Risiken - Der Bericht des Büros für TechnikfolgenAbschätzung zur Genomanalyse. Berlin: Sigma.

Hitzler, Ronald/Michaela Pfadenhauer, 1999: Reflexive Mediziner? Die Definition professioneller Kompetenz als standespolitisches Problem am Übergang zu einer "anderen" Moderne. In: Christoph Maeder/Claudine BurtonJeangros/Mary Haour-Knipe (eds.), Gesundheit, Medizin und Gesellschaft - 
Beiträge zur Soziologie der Gesundheit. Zürich: Seismo, 97- 115.

Japp, Klaus P., 1997: Zur Beobachtung von Nichtwissen. In: Soziale Systeme, 289312.

Japp, Klaus P., 1999: Die Unterscheidung von Nichtwissen. In: TA-DatenbankNachrichten 8, 25-32.

Japp, Klaus P., 2002a: Struktureffekte öffentlicher Risikokommunikation auf Regulierungsregime. Zur Funktion von Nichtwissen im BSE-Konflikt. In: Christoph Engel/Jost Halfmann/ Martin Schulte (eds.), Wissen - Nichtwissen Unsicheres Wissen. Baden-Baden: Nomos, 35-74.

Japp, Klaus P., 2002b: Wie normal ist Nichtwissen? In: Zeitschrift für Soziologie 31, 435-439.

Joss, Simon/Sergio Bellucci (eds.), 2002: Participatory Technology Assessment European Perspectives. London: University of Westminster Press.

Knorr Cetina, Karin, 1999: Epistemic Cultures - How the Sciences Make Knowledge. Cambridge, MA: Harvard University Press.

Kratzer, Nick, 2003: Arbeitskraft in Entgrenzung. Berlin: Sigma.

Latour, Bruno, 1993: We Have Never Been Modern. Cambridge, MA: Harvard University Press.

Latour, Bruno, 1999: Pandora's Hope. Essays on the Reality of Science Studies. Cambridge, MA: Harvard University Press.

Lemke, Thomas, 2004: Veranlagung und Verantwortung. Genetische Diagnostik zwischen Selbstbestimmung und Schicksal. Bielefeld: transcript.

Luhmann, Niklas, 1990: Der medizinische Code. In: Niklas Luhmann (ed.), Soziologische Aufklärung 5. Konstruktivistische Perspektiven. Opladen: West deutscher Verlag, 183- 196.

Luhmann, Niklas, 1991: Soziologie des Risikos. Berlin: de Gruyter.

Luhmann, Niklas, 1992: Ökologie des Nichtwissens. In: Niklas Luhmann (ed.), Beobachtungen der Moderne. Opladen: Westdeutscher Verlag, 149- 220.

Luhmann, Niklas, 1995: Die Soziologie des Wissens: Probleme ihrer theoretischen Konstruktion. In: Niklas Luhmann, Gesellschaftsstruktur und Semantik Studien zur Wissenssoziologie der modernen Gesellschaft. Frankfurt/M .: Suhrkamp, 151- 180.

May, Stefan/Markus Holzinger, 2003: Autonomiekonflikte der Humangenetik - Professionssoziologische und professionsrechtliche Aspekte einer Theorie reflexiver Modernisierung. Opladen: Leske + Budrich.

Merton, Robert K., 1987: Three Fragments from A Sociologist's Notebook: Esta- blishing the Phenomenon, Specified Ignorance, and Strategic Research Materials. In: Annual Review of Sociology 13, 1-28.

Minssen, Heiner (ed.), 2000: Begrenzte Entgrenzung. Berlin: Sigma.

Nippert, Irmgard, 1991: History of Prenatal Genetic Diagnosis in the Federal Republic of Germany. In: Margaret Reid (ed.), The Diffusion of Four Prenatal Screening Tests Across Europe. London: King's Fund Centre, 49-69.

Nippert, Irmgard, 1999: Entwicklung der pränatalen Diagnostik. In: GenEthisches Netzwerk/Gabriele Pichlhofer (eds.), Grenzverschiebungen - Politische und ethische Aspekte der Fortpflanzungsmedizin. Frankfurt/M.: Mabuse, 63-80.

Nowotny, Helga, 2005: Experten, Expertisen und imaginierte Laien. In: Alexander Bogner/Helge Torgersen (eds.), Wozu Experten? Ambivalenzen der Beziehung von Wissenschaft und Politik. Wiesbaden: VS, 33-44.

Powell, Walter W., 1991: Neither Market nor Hierarchy: Network Forms of Organization. In: Grahame Thompson/ Jennifer Frances/Rosalind Levacic/ Jeremy Mitchell (eds.), Markets, Hierarchy and Networks. London: Sage, 265-278.

Reif, Maria/Helmut Baitsch, 1986: Genetische Beratung - Hilfestellung für eine selbstverantwortliche Entscheidung? Berlin: Springer.

Rose, Nikolas (1998): Inventing Our Selves. Psychology, Power and Personhood. Cambridge University Press: Cambridge

Sauer, Dieter/Volker Döhl, 1997: Die Auflösung des Unternehmens? Entwicklungstendenzen der Unternehmensreorganisation in den 90er Jahren. In: IfS/INIFES/ISF/SOFI (ed.), Jahrbuch sozialwissenschaftliche Technikberichterstattung '96 - Schwerpunkt: Reor ganisation. Berlin: Sigma, 19-76.

Scheuch, Erwin K., 2003: Die Bedeutung des Zeitgeistes für die Medizin. In: Soziale Welt 54, 389-404.

Scholz, Christine, 1995: Biographie und molekulargenetische Diagnostik. In: Elisabeth Beck-Gernsheim (ed.), Welche Gesundheit wollen wir? Frankfurt/M., 33-72.

Singer, Peter, 1979: Practical Ethics. Cambridge: Cambridge University Press.

Sperber, Katharina, 2001: Selektion diesseits des Rubikons. In: Frankfurter Rundschau vom 15.6.2001.

Stehr, Nico, 2000: Die Zerbrechlichkeit moderner Gesellschaften. Die Stagnation der Macht und die Chancen des Individuums. Weilerswist: Velbrück.

Tooley, Michael, 1979: Decisions to Terminate Life and the Concept of 
Person. In: John Ladd (ed.), Ethical Issues Relating to Life and Death. New York: Oxford University Press, 62-93.

van den Daele, Wolfgang, 1996: Objektives Wissen als politische Ressource. Experten und Gegenexperten im Diskurs. In: Wolfgang van den Daele/Friedhelm Neidhardt (eds.), Kommunikation und Entscheidung. WZB Jahrbuch 1996. Berlin: Sigma, 297- 326.

Viehöver, Willy, 2005: Der Experte als Platzhalter und Interpret moderner Mythen: das Beispiel der Stammzelldebatte. In: Alexander Bogner/ Helge Torgersen (eds.), Wozu Experten? Ambivalenzen der Beziehung von Wissenschaft und Politik. Wiesbaden: VS, 149171.

Viehöver, Willy/Robert Gugutzer/Reiner Keller/Christoph Lau, 2004: Vergesellschaftung der Natur - Naturalisierung der Gesellschaft. In: Ulrich Beck/ Christoph Lau (eds.), Entgrenzung und Entscheidung: Was ist neu an der Theorie reflexiver Modernisierung? Frankfurt/M.: Suhrkamp, 65-94.

von Kaisenberg, Constantin/Walter Jonat/ Hans-Jürgen Kaatsch, 2005: Spätinterruptio und Fetozid - das Kieler Modell. In: Deutsches Ärzteblatt 102, A133A136.

Waldschmidt, Anne, 1996: Das Subjekt in der Humangenetik - Expertendiskurse zu Programmatik und Konzeption der genetischen Beratung 1945-1990. Münster: Westfälisches Dampfboot.

Wehling, Peter, 2003a: Das Recht auf Nichtwissen in der Humangenetik - ein "Irrläufer" in der Wissensgesellschaft? In: Jutta Allmendinger (ed.), Entstaatlichung und soziale Sicherheit. Verhandlungen des 31. Kongresses der Deutschen Gesellschaft für Soziologie in Leipzig 2002. Opladen: Leske + Budrich (CD-Rom).

Wehling, Peter, 2003b: Die Schattenseite der Verwissenschaftlichung. Wissenschaftliches Nichtwissen in der Wissensgesellschaft. In: Stefan Böschen/ Ingo Schulz-Schaeffer (eds.), Wissenschaft in der Wissensgesellschaft. Wiesbaden: West deutscher Verlag, 119-142.

Wehling, Peter, 2004: Weshalb weiß die Wissenschaft nicht, was sie nicht weiß? - Umrisse einer Soziologie des wissenschaftlichen Nichtwissens. In: Stefan Böschen/Peter Wehling (eds.), Wissenschaft zwischen Folgen verantwortung und Nichtwissen. Aktuelle Perspektiven der Wissenschaftsforschung. Wiesbaden: VS, 35-105.

Willke, Helmut, 2002: Dystopia - Studien zur Krisis des Wissens in der modernen Gesellschaft. Frankfurt/M.: Suhrkamp.

Wynne, Brian, 1992: Uncertainty and environmental learning. Reconceiving science and policy in the preventive paradigm. In: Global Environmental Change 2, 111- 127. 